\title{
Pensononowoor
}

2014, vol. 72, 47-56

http://dx.doi.org/10.12657/denbio.072.004

\author{
Andrzej Pacholczak, Stefan Pietkiewicz
}

\section{Rhizogenesis and gas exchange in dogwood stem cuttings as affected by two biostimulators}

\author{
Received: 14 October 2013; Accepted: 26 February 2014
}

\begin{abstract}
The UE-imposed restrictions on the manufacture and use of plant protection chemicals necessitate screening for new substances that are more environmentally friendly. Biopreparations may constitute such a group; therefore, studies on their efficiency in the production of plant material are needed. This study evaluated the effects of two biostimulators on rhizogenesis and the gas exchange rate (respiration, photosynthesis, transpiration) of stem cuttings of dogwood (Cornus alba) as compared to conventional treatments with a rooting powder containing $2 \%$ auxin IBA and with aqueous IBA solution. Both biopreparations enhanced rhizogenesis; their efficiency varied depending on the cultivar, biostimulator applied, and the number of treatments. There was no relationship between rhizogenesis and physiological parameters tested. The experiments demonstrated that at least some biopreparations have potential in commercial production but their effectiveness may be different in different species and under different conditions.
\end{abstract}

Additional key words: leafy shrubs, rooting, auxin, respiration, photosynthesis, transpiration

Addresses: Andrzej Pacholczak, Department of Ornamental Plants, Faculty of Horticulture, Biotechnology and Landscape Architecture (WULS-SGGW), Nowoursynowska 159, 02-776 Warsaw, Poland, e-mail: pacholczak@poczta.onet.pl

Stefan Pietkiewicz Departament of Plant Physiology, Faculty of Agriculture and Biology, Warsaw University of Life Sciences (WULS-SGGW), Nowoursynowska 159, 02-776 Warsaw, Poland, e-mail: stefan_pietkiewicz@sggw.pl

\section{Introduction}

In the ornamental nursery production, commercial rooting powders containing synthetic auxins such as IAA (indole-3-acetic acid), NAA (naphtyl1-acetic acid) or IBA (indolyl-3-butyric acid), are routinely used for enhancing rhizogenesis in stem cuttings (Jankiewicz 1997). The UE-imposed restrictions on the manufacture and use of plant protection chemicals - synthetic auxins included - create a new production environment. This imposes on the nurseryman a need to screen for new substances that are environmentally friendly and yet effective in the production of plant material (Khan et al. 2009). Biostimulators may constitute such a group as they contain substance little affecting the environment. Biostimulators have been considered as biological substances that stimulate processes within plants. They are single- or multi-compound preparations containing extracts from plants or animals. Their effect is a result of their influence on plant metabolism (Basak 2008). They are used to obtain the highest possible and the best quality yields, especially under environmental conditions unfavorable for plant growth and 
development (Przybysz et al. 2008). Biostimulators enhance the uptake of macro- and microelements and their translocation within plants, increase the respiration rate and root growth, improve photosynthesis and other metabolic processes (Costa et al. 2001; Gawrońska et al. 2008, Przybysz et al. 2008). They enhance plant resistance to stresses (Gawrońska et al. 2008), accelerate flowering and fruit set (Bai et al. 2007), improve the soil water-holding capacity and maintain optimal soil pH (Matysiak et al. 2010). Biopreparations such as AlgaminoPlant (Matysiak et al. 2010) or Route (Horne and Leitch 2006) have been reported to positively affect nursery plant production. Tests of their efficacy in propagation of ornamental woody plants appear promising (Pacholczak et al. 2010; 2012).

Gas exchange of plants involves respiration, photosynthesis and transpiration - processes affected by biostimulators (Gawrońska et al. 2008, Przybysz et al. 2008). The key parameter in each of these processes is stomatal conductance $\left(\mathrm{g}_{\mathrm{s}}\right)$. Stomata can introduce carbon dioxide into the leaf inner space and release water vapor into the atmosphere.

This study was set out to compare two biopreparations, AlgaminoPlant and Route, with a commercial rooting powder containing synthetic auxin IBA (2\%) and with the water solution of IBA $\left(200 \mathrm{mg} \cdot \mathrm{dm}^{-3}\right)$ on two cultivars of the popular ornamental shrub dogwood (Cornus alba). Dogwoods are commonly planted both in private and public green areas; they are propagated by stem cuttings (Hartmann et al. 2002). Dogwood cultivars are well known to differ in their ability to form roots; therefore the experiments were done on two cultivars known to be different in their rooting characteristics. Since biostimulators had been shown to affect the photosynthesis and respiration rate of plants (Przybysz et al. 2008), an attempt was made to detect a relationship between some parameters of gas exchange in cuttings, as influenced by treatments, and the subsequent rhizogenesis.

\section{Material and methods}

The plant material in this study were two cultivars of dogwood (Cornus alba L.) 'Aurea' and 'Elegantissima'. The former is considered easier to root than the latter (Kryt, personal communication 2010). The experiments were initiated on June 27 of 2011 and 2012 in a commercial nursery in Wola Prażmowska. Semi lignified two-nodal stem cuttings $5 \mathrm{~cm}$ long were prepared from stock plants free of pathogens and diseases. Cuttings were inserted to the depth of $2.0 \mathrm{~cm}$ into a mixture of peat, perlite and sand (2:1:1), pH 5.0, in styrofoam boxes. The mixture was thoroughly wetted and pressed, and covered with 0.5 $\mathrm{cm}$ layer of coarse sand. Rooting took place in plastic
Table 1. Rainfall and mean temperatures in 2011-2012 (Experimental Station IMiGW Skierniewice)

\begin{tabular}{lrrrr}
\hline \multicolumn{1}{c}{ Month } & \multicolumn{1}{c}{ III } & \multicolumn{1}{c}{ IV } & \multicolumn{1}{c}{ V } & \multicolumn{1}{c}{ VI } \\
\hline 2011 rainfall $(\mathrm{mm})$ & 15.1 & 80.5 & 38.9 & 106.1 \\
2012 rainfall $(\mathrm{mm})$ & 23.2 & 52.8 & 21.4 & 57.7 \\
2011 mean monthly temp. $\left({ }^{\circ} \mathrm{C}\right)$ & 3.0 & 10.5 & 14.4 & 18.6 \\
2012 mean monthly temp $\left({ }^{\circ} \mathrm{C}\right)$ & 5.0 & 9.4 & 15.6 & 17.4 \\
\hline
\end{tabular}

tunnels equipped with automatic watering and mist systems as well as shading devices. The boxes were covered with opaque foil to provide $100 \% \mathrm{RH}$. According to a routine procedure in the nursery, every two weeks cuttings were sprayed against Botrytis with $0.2 \%$ Rovral or Topsin although the pesticide application could have affected rhizogenesis as such. Lack of this treatment could be a threat for cuttings and potentially induces a disease spread in the whole propagation tunnel.

The climatic conditions during growth of stock plants before harvesting the cuttings, i.e. means of the monthly temperatures and rainfall are gathered in Table 1. The data were included to allow to deduce the environmental impact on physiological status of the field-grown stock plants from which the cuttings were gathered.

Night temperature during rooting was $15-20^{\circ} \mathrm{C}$ while daily temperatures ranged between 25 and $35^{\circ} \mathrm{C}$.

\section{Biostimulators}

AlgaminoPlant (Varichem, Poland) is a liquid preparation produced on the base of a seaweed extract (18\%) from Sargassum, Laminaria, Ascophyllum and Fuscus. It contains three groups of plant hormones: gibberellins $\left(50 \mathrm{mg} \cdot \mathrm{dm}^{-3}\right)$, cytokinins (5 $\left.\mathrm{mg}^{*} \mathrm{dm}^{-3}\right)$ and auxins $\left(30 \mathrm{mg} \cdot \mathrm{dm}^{-3}\right)$. It is supplemented by potassium salts of amino acids at $10 \%$. The preparation enhances the macro- and microelement uptake and translocation within plants (Matysiak et al. 2010), increases the respiration rate and root growth, participates in photosynthesis and other metabolic processes, enhances plant resistance to stresses, accelerates flowering and fruit set (Anyszka and Pałczyński 2006; Dobrzański et al. 2008). It also improves the soil water-holding capacity and maintains optimal soil pH (Matysiak et al. 2010).

Route (Dalgety, Poland) is a formulation of zinc ammonium acetate (ZAA) composed of acetic acid, water, ammonium and zinc oxide. Zinc helps plants to overcome environmental stresses and enhances their productivity through a better development of root system and a more efficient irradiance use (Fraser and Percival 2003). Route increases the endogenous auxin content and reinforces (about 18\%) cell walls, thus reducing their porosity and indirect- 
ly decreasing nutrient loses from cells (Horne and Leitch 2006). ZAA action in a process of rhizogenesis is associated with stimulation of endogenous auxins' biosynthesis, what changes the auxin to cytokinin ratio. This in turn results in a more abundant production of auxillary roots.

\section{Methods}

The cuttings were sprayed with water solutions of AlgaminoPlant $(0.2 \%)$ or Route $(0.1 \%)$ once, twice or three times during the rooting period (biostimulators' concentrations were based on the recommendations of the producers and checked during preliminary experiments). The control treatment consisted of cuttings treated with a commercial rooting powder routinely used in nursery production with the synthetic auxin indolyl-3-butyric acid (IBA) as the active agent. Auxins may be applied to the cuttings' bases either as powders or in aqueous solutions. The numerous trials have also proved efficacy of the foliar auxin application. This method allows to repeat a treatment and can replace the traditional way of application, to the cuttings' bases. Spraying cuttings placed in a rooting medium allows to save a preparation as well as labor thus lowering the overall production costs (Szydło and Maksim 1997; Szydło and Pacholczak 2001; Pacholczak et al. 2005). Therefore, in the experiments the auxin was applied in two forms: either directly to the bases of cuttings in the powder form (Rhizopon AA; $2 \%$ IBA), or by spraying cuttings with aqueous solution of $200 \mathrm{mg} \cdot \mathrm{dm}^{-3}$ IBA. The ultimate control were cuttings sprayed with distilled water.

The first treatment was on June 27, the start of the experiment. Additional one or two treatments were one week apart, on July 4 and July 11 . Solutions were sprayed with a hand pressure sprayer (Kwazar, Poland) of $2 \mathrm{dm}^{3}$ volume. The experiments consisted of

Table 2. List of treatments

\begin{tabular}{|c|c|c|c|}
\hline $\begin{array}{l}\text { Treat- } \\
\text { ment }\end{array}$ & $\begin{array}{c}\text { Preparation } \\
\text { used }\end{array}$ & Concentration & $\begin{array}{l}\text { Number of treat- } \\
\text { ments }\end{array}$ \\
\hline 1 & $\begin{array}{l}\text { Control - } \\
\text { water }\end{array}$ & - & - \\
\hline 2 & $\begin{array}{c}\text { Rhizopon } \\
\text { AA }\end{array}$ & powder $2 \%$ IBA & $1 \times$ powder \\
\hline 3 & AuxinIBA & $\begin{array}{c}200 \mathrm{mg}^{*} \mathrm{dm}^{-3} \\
\text { water }\end{array}$ & $1 \times$ spraying \\
\hline 4 & Route & $0.1 \%$ & $1 \times$ spraying \\
\hline 5 & Route & $0.1 \%$ & $2 \times$ spraying \\
\hline 6 & Route & $0.1 \%$ & $3 \times$ spraying \\
\hline 7 & $\begin{array}{l}\text { Algamino- } \\
\text { Plant }\end{array}$ & $0.2 \%$ & $1 \times$ spraying \\
\hline 8 & $\begin{array}{l}\text { Algamino- } \\
\text { Plant }\end{array}$ & $0.2 \%$ & $2 \times$ spraying \\
\hline 9 & $\begin{array}{l}\text { Algamino- } \\
\text { Plant }\end{array}$ & $0.2 \%$ & $3 \times$ spraying \\
\hline
\end{tabular}

Table 3. Evaluation scale of the root development

\begin{tabular}{ccc}
\hline No. & Root characteristics & Score \\
\hline 1 & No visible roots & 1 \\
2 & $1-3$ roots (over 1 cm long) & 2 \\
3 & $4-5$ roots (2-4 cm long) & 3 \\
4 & $6-7$ roots (4-5 cm long) & 4 \\
5 & Well developed, branched root system & 5 \\
\hline
\end{tabular}

nine treatments (Table 2), each in three replications, with 20 cuttings per replication. Rooting frequencies were scored after seven weeks, and this included two parameters: the percentage of rooted cuttings and the degree of rooting. The latter was scored on a 5-point scale rating the development of the root ball (Table 3). The scores for the degree of rooting represent means of three independent observations by trained personnel.

On July 12 the following measurements of the gas exchange parameters were done:

- $\mathrm{R}_{\mathrm{d}}$ - respiration rate $\left(\mu \cdot \mathrm{mol} \mathrm{CO} \cdot \mathrm{m}^{-2} \cdot \mathrm{s}^{-1}\right)$

- $\mathrm{P}_{\mathrm{n}}$ - net photosynthetic rate $\left(\mu \cdot \mathrm{mol} \mathrm{CO} \cdot \mathrm{m}^{-2} \cdot \mathrm{s}^{-1}\right)$

- $\mathrm{T}^{\mathrm{n}}$ - transpiration rate $\left(\mathrm{mol} \mathrm{H}_{2} \mathrm{O} \cdot \mathrm{m}^{-2} \cdot \mathrm{s}^{-1}\right)$

- $\mathrm{g}_{\mathrm{s}}$ - stomatal conductance $\left(\mathrm{mmol} \mathrm{H}_{2} \mathrm{O} \cdot \mathrm{m}^{-2} \cdot \mathrm{s}^{-1}\right)$

The parameters of gas exchanged were measured by CIRAS-2 gas analyzer (PP System Inc., Amesbury, MA, USA). The measurements were done in triplicates, at noon, under natural irradiance of 1000 $1400 \mu \mathrm{mol} \mathrm{PAR} \cdot \mathrm{m}^{-2} \cdot \mathrm{s}^{-1}$ at $25^{\circ} \mathrm{C}$ and $\mathrm{CO}_{2}$ concentration 300-350 $\mu \mathrm{mol} \mathrm{mol}^{-1}$ air. The conditions during measurements were: temperature $30-39^{\circ} \mathrm{C}$ and relative humidity $90-100 \%$. The respiration rate was determined after shading the measurement chamber and extinction of photosynthesis. When measured with an infra red gas analyzer, the negative photosynthetic rate is equal to the respiration rate.

Statistical analyses

To compare the means, percentages of rooted cuttings were transformed according to Bliss (Wójcik and Laudański 1989), while the degree of rooting by root transformation: $y=x^{2}+(x+1)^{2}$. The above data were subjected to the 2-factorial ANOVA and tested by the Duncan's test at $\alpha=0.05$. Results of the gas exchange analyses were subjected to the 2-factorial ANOVA and the means were compared by the Duncan's test at $\alpha=0.05$.

\section{Results}

\section{Cornus alba 'Aurea'}

Across all treatments, cuttings rooted better in the second year of the experiment. In both years, untreated cuttings rooted relatively well, averaging $66.7 \%$ (Table 4). The commercial rooting powder Rhizopon AA appeared the least effective of all treatments; IBA sprayed in water solution improved the percentage 
of rooting by ca $10 \%$. The best rooting percentage was observed after triple treatment with AlgaminoPlant which increased the mean percentage of rooted cuttings by nearly $30 \%$ relative to control. Increased percentages of rooted cuttings were also obtained after a single application of AlgaminoPlant and one or two applications of Route. The triple application of Route was inefficient in both years.

During seven weeks of the experiment, control (untreated) cuttings developed few short roots (Table 5) and their average degree of rooting was 2.3. All treatments - except the triple application of Route - improved rhizogenesis. Triple application of AlgaminoPlant was significantly better than a single treatment.

The average respiration rates of cuttings leaves in 'Aurea' ranged between 0.8 and $1.25 \mu \mathrm{mol} \mathrm{CO}_{2}$ $\mathrm{m}^{-2} \mathrm{~s}^{-1}$. As compared to control cuttings $(0.8 \mu \mathrm{mol}$ $\mathrm{CO}_{2} \mathrm{~m}^{-2} \mathrm{~s}^{-1}$ ) the significantly higher average $\mathrm{R}_{\mathrm{d}}$ value were found in cuttings treated twice and three times with Route or sprayed twice with AlgaminoPlant. In 2011 the auxin treatment significantly increased the respiration efficiency relative to control, similarly as a single application of AlgaminoPlant. In 2012 the respiration rate was much higher (by 50-70\%), especially in cuttings after triple application of AlgaminoPlant and double application of Route while auxins did not affect this parameter (Table 6).

The average photosynthetic rate of cuttings ranged between 2.65 and $4.45 \mu \mathrm{mol} \mathrm{CO} \mathrm{m}^{-2} \mathrm{~s}^{-1}$. All treatments that increased rooting also raised the photosynthetic rate $\left(\mathrm{P}_{\mathrm{n}}\right)$ above that of control untreated cuttings, except in the case of the single spray with Route. In 2011 the photosynthetic rate was increased considerably due to the following treatments: application of IBA (89\%), double $(100 \%)$ or triple $(92 \%)$ applications of AlgaminoPlant and double applications of Route (114\%). In 2012, changes in $\mathrm{P}_{\mathrm{n}}$ following treatments with IBA and biostimulators were not significant, with the exception of Rhizopon AA and threefold Route spraying, where the increase in $\mathrm{P}_{\mathrm{n}}$ was $68 \%$ and $56 \%$ for Rhizopon AA and Route, respectively (Table 7).

The average transpiration rate of leaves $(\mathrm{T})$ ranged between 4.35 and $7.80 \mathrm{mmol} \mathrm{H}_{2} \mathrm{O} \mathrm{m}^{-2} \mathrm{~s}^{-1}$. All the averages were significantly higher except

Table 4. Effect of biostimulators on the percentage of rooted cuttings in Cornus alba 'Aurea' (2011 and 2012). The last column contains general means for all the treatments, separately for both years

\begin{tabular}{crrrrrrrrrr}
\hline Treatment/year & \multirow{2}{*}{ C } & \multirow{2}{*}{ Rh AA } & \multicolumn{1}{c}{ IBA } & Alga 1x & Alga 2x & Alga 3x & Route 1x & Route 2x & Route 3x & $\begin{array}{c}\text { Mean/ } \\
\text { year }\end{array}$ \\
\hline 2011 & $57.3 \mathrm{abc}^{*}$ & $51.1 \mathrm{ab}$ & $63.7 \mathrm{bcd}$ & $68.6 \mathrm{cde}$ & $67.6 \mathrm{~cd}$ & $94.3 \mathrm{~h}$ & $74.6 \mathrm{def}$ & $76.8 \mathrm{efg}$ & $44.7 \mathrm{a}$ & $67.6 \mathrm{a}$ \\
2012 & $76.3 \mathrm{def}$ & $92.2 \mathrm{fgh}$ & $93.0 \mathrm{gh}$ & $92.1 \mathrm{fgh}$ & $89.1 \mathrm{fgh}$ & $90.1 \mathrm{fgh}$ & $98.7 \mathrm{~h}$ & $84.8 \mathrm{efg}$ & $85.3 \mathrm{fgh}$ & $\mathbf{8 8 . 5} \mathrm{b}$ \\
Mean for treatment & $66.7 \mathrm{a}$ & $\mathbf{7 1 . 7 \mathrm { ab }}$ & $\mathbf{7 8 . 3 \mathrm { bc }}$ & $\mathbf{8 0 . 3 \mathrm { bcd }}$ & $\mathbf{7 8 . 3 \mathrm { bc }}$ & $\mathbf{9 4 . 2 \mathrm { d }}$ & $\mathbf{8 6 . 7 \mathrm { cd }}$ & $\mathbf{8 0 . 8 \mathrm { bcd }}$ & $\mathbf{6 5 . 0 \mathrm { a }}$ & \\
\hline
\end{tabular}

* - The means followed by the same letters do not differ significantly at $\alpha=0.05$

Table 5. Effect of biostimulators on the degree of rooting in cuttings of Cornus alba 'Aurea' (2011 and 2012). The last column contains general means for all the treatments, separately for both years

\begin{tabular}{ccccccccccc}
\hline Treatment/year & C & Rh AA & IBA & Alga 1x & Alga 2x & Alga 3x & Route 1x & Route 2x & Route 3x & $\begin{array}{c}\text { Mean/ } \\
\text { year }\end{array}$ \\
\hline 2011 & $1.6 \mathrm{a}^{*}$ & $1.8 \mathrm{a}$ & $2.2 \mathrm{ab}$ & $2.6 \mathrm{bc}$ & $2.6 \mathrm{bc}$ & $3.7 \mathrm{ef}$ & $2.6 \mathrm{bc}$ & $2.8 \mathrm{c}$ & $1.8 \mathrm{a}$ & $2.5 \mathrm{a}$ \\
2012 & $2.8 \mathrm{c}$ & $3.9 \mathrm{f}$ & $3.8 \mathrm{ef}$ & $2.9 \mathrm{~cd}$ & $3.2 \mathrm{def}$ & $3.3 \mathrm{def}$ & $3.5 \mathrm{def}$ & $2.9 \mathrm{~cd}$ & $3.0 \mathrm{~cd}$ & $3.3 \mathrm{~b}$ \\
Mean for treatment & $2.3 \mathrm{a}$ & $2.9 \mathrm{bc}$ & $3.0 \mathrm{~cd}$ & $2.8 \mathrm{bc}$ & $3.0 \mathrm{~cd}$ & $3.5 \mathrm{~d}$ & $3.1 \mathrm{~cd}$ & $2.9 \mathrm{bc}$ & $2.4 \mathrm{a}$ & \\
\hline
\end{tabular}

* - as in Table 4

Table 6. The effect of biostimulators on respiration rates $\left(\mu \mathrm{mol} \mathrm{CO} \mathrm{Cm}^{-2} \mathrm{~s}^{-1}\right)$ of in leaves of cuttings from Cornus alba 'Aurea' (2011 and 2012). The last column contains general means for all the treatments, separately for both years

\begin{tabular}{|c|c|c|c|c|c|c|c|c|c|c|}
\hline Treatment/year & $\mathrm{C}$ & $\mathrm{Rh}$ AA & IBA & Alga 1x & Alga $2 x$ & Alga $3 x$ & Route $1 \mathrm{x}$ & Route $2 \mathrm{x}$ & Route $3 \mathrm{x}$ & $\begin{array}{c}\text { Mean/ } \\
\text { year }\end{array}$ \\
\hline 2011 & $0.5 \mathrm{ab}^{*}$ & $0.8 \mathrm{c}$ & $0.9 \mathrm{de}$ & $0.8 \mathrm{c}$ & $0.6 \mathrm{~b}$ & $0.4 \mathrm{a}$ & $0.6 \mathrm{~b}$ & $0.6 \mathrm{~b}$ & $0.6 \mathrm{~b}$ & $0.65 \mathrm{a}$ \\
\hline 2012 & $1.1 \mathrm{ef}$ & $1.1 \mathrm{f}$ & $1.1 \mathrm{f}$ & $1.4 \mathrm{~g}$ & $1.2 \mathrm{fg}$ & $1.9 \mathrm{i}$ & $1.6 \mathrm{~h}$ & $1.9 \mathrm{i}$ & $1.7 \mathrm{~h}$ & $1.44 \mathrm{~b}$ \\
\hline Mean for treatment & $0.8 \mathrm{a}$ & $0.95 \mathrm{abc}$ & $1.0 \mathrm{abc}$ & $1.1 \mathrm{abc}$ & $0.9 \mathrm{a}$ & $1.15 b c$ & $1.1 \mathrm{abc}$ & $1.25 \mathrm{c}$ & $1.15 b c$ & \\
\hline
\end{tabular}

* - as in Table 4

Table 7. The effect of biostimulators on photosynthetic rates $\left(\mu \mathrm{mol} \mathrm{CO} \mathrm{m}^{-2} \mathrm{~s}^{-1}\right)$ in leaves of cuttings from Cornus alba 'Aurea' (2011 and 2012). The last column contains general means for all the treatments, separately for both years

\begin{tabular}{crrrrrrrrrr}
\hline Treatment/year & \multirow{2}{*}{ C } & \multirow{2}{*}{ Rh AA } & \multicolumn{1}{c}{ IBA } & Alga 1x & Alga 2x & Alga 3x & Route 1x & Route 2x & Route 3x & $\begin{array}{c}\text { Mean/ } \\
\text { year }\end{array}$ \\
\hline 2011 & $2.8 \mathrm{abc}$ & $3.9 \mathrm{~cd}$ & $5.3 \mathrm{de}$ & $3.5 \mathrm{c}$ & $5.6 \mathrm{e}$ & $5.4 \mathrm{e}$ & $3.2 \mathrm{abcd}$ & $6.0 \mathrm{e}$ & $2.5 \mathrm{ab}$ & $4.24 \mathrm{~b}$ \\
2012 & $2.5 \mathrm{ab}$ & $4.2 \mathrm{~cd}$ & $2.4 \mathrm{a}$ & $2.3 \mathrm{ab}$ & $2.5 \mathrm{abcd}$ & $3.4 \mathrm{abcd}$ & $3.0 \mathrm{abcd}$ & $2.9 \mathrm{abc}$ & $3.9 \mathrm{~cd}$ & $3.00 \mathrm{a}$ \\
Mean for treatment & $2.65 \mathrm{a}$ & $4.05 \mathrm{bc}$ & $3.85 \mathrm{bc}$ & $2.9 \mathrm{ab}$ & $4.05 \mathrm{bc}$ & $4.4 \mathrm{c}$ & $3.1 \mathrm{ab}$ & $4.45 \mathrm{c}$ & $3.2 \mathrm{abc}$ & \\
\hline
\end{tabular}

\footnotetext{
* - as in Table 4
} 
that of the single Route application. In 2011 all the treatments intensified this process and the highest increase in the $\mathrm{E}$ as compared to the control was observed following Rhizopone application (Table 8). In 2012 , transpiration was significantly higher (by $17 \%$ on the average) than in 2011. Here, Rhizopone application did not affect transpiration though the water IBA solution increased it significantly relative to control. So did the treatments with both biostimulators, except that with the single Route spraying.

The average stomatal conductance $\left(\mathrm{g}_{\mathrm{s}}\right)$ in leaves ranged between 0.244 (control) to $0.653 \mathrm{mmol} \mathrm{H}_{2} \mathrm{O}$ $\mathrm{m}^{-2} \mathrm{~s}^{-1}$ (triple sprayings with AlgaminoPlant) having significantly increased after all the treatments (Table 9 ). This tendency was seen in both years. In the second year of experiment after application of the auxin water solution and AlgaminoPlant (1-3 sprays) stomatal conductance was nearly tripled. In both years Route was less effective in this regard.

\section{Cornus alba 'Elegantissima'}

The highest average rooting percentages were obtained following a single or double Route applications (Table 10). Also AlgaminoPlant used once or twice significantly increased average rooting percentage. The additional third application of two biostimulators did not improve rooting relative to control. No significant differences in the average percentage of rooted cuttings were observed between the years.

During seven weeks of the experiment control cuttings developed a few short roots and their degree of rooting was 2.4. Spraying cuttings with the water IBA solution significantly improved rhizogenesis increasing the rooting degree to 3.0 (Table 11).

The average respiration rates of leaves in cuttings from 'Elegantissima' ranged from 0.85 to 1.65 $\mu \mathrm{mol} \mathrm{CO} \mathrm{m}^{-2} \mathrm{~s}^{-1}$ (Table 12). The lowest rates were in control cuttings and those treated with auxin. Both biopreparations increased the average $R_{d}$ values. Generally, the respiration in 2012 decreased by $35 \%$ as compared to 2011 . The respiration rate in

Table 8. The effect of biostimulators on the transpiration rate $\left(\mathrm{mmol} \mathrm{H}_{2} \mathrm{O} \mathrm{m}^{-2} \mathrm{~s}^{-1}\right)$ in leaves of cuttings from Cornus alba 'Aurea' (2011 and 2012). The last column contains general means for all the treatments, separately for both years

\begin{tabular}{|c|c|c|c|c|c|c|c|c|c|c|}
\hline $\begin{array}{c}\text { Treatment/ } \\
\text { year }\end{array}$ & $\mathrm{C}$ & Rh AA & IBA & Alga $1 \mathrm{x}$ & Alga $2 x$ & Alga $3 x$ & Route $1 \mathrm{x}$ & Route $2 \mathrm{x}$ & Route $3 \mathrm{x}$ & $\begin{array}{c}\text { Mean/ } \\
\text { year }\end{array}$ \\
\hline 2011 & $3.9 \mathrm{a}^{*}$ & $8.2 \mathrm{hi}$ & $6.7 \mathrm{fg}$ & $5.2 \mathrm{bc}$ & $5.3 \mathrm{bc}$ & $6.1 \mathrm{ef}$ & $6.2 \mathrm{efg}$ & $5.9 \mathrm{de}$ & $5.3 \mathrm{bc}$ & $5.9 \mathrm{a}$ \\
\hline 2012 & $4.8 \mathrm{~b}$ & $5.5 \mathrm{bc}$ & $8.9 \mathrm{j}$ & $7.9 \mathrm{~h}$ & $8.5 \mathrm{~h}$ & $6.5 \mathrm{efg}$ & $5.0 \mathrm{bc}$ & $6.0 \mathrm{de}$ & $6.8 \mathrm{~g}$ & $6.7 \mathrm{~b}$ \\
\hline Mean for treatment & $4.35 \mathrm{a}$ & $6.85 \mathrm{~cd}$ & $7.8 \mathrm{~d}$ & $6.55 \mathrm{bcd}$ & $6.9 \mathrm{~cd}$ & $6.3 \mathrm{bc}$ & $5.6 \mathrm{ab}$ & $5.95 \mathrm{bc}$ & $6.05 \mathrm{bc}$ & \\
\hline
\end{tabular}

* - as in Table 4

Table 9. The effect of biostimulators on stomatal conductance $\left(\mathrm{g}_{\mathrm{s}}\right)\left(\mathrm{mmol} \mathrm{H}_{2} \mathrm{O} \mathrm{m}^{-2} \mathrm{~s}^{-1}\right)$ in leaves of cuttings from Cornus alba 'Aurea' in (2011 and 2012). The last column contains general means for all the treatments, separately for both years

\begin{tabular}{|c|c|c|c|c|c|c|c|c|c|c|}
\hline Treatment/year & $\mathrm{C}$ & Rh AA & IBA & Alga $1 \mathrm{x}$ & Alga $2 x$ & Alga $3 x$ & Route $1 \mathrm{x}$ & Route $2 \mathrm{x}$ & Route $3 \mathrm{x}$ & $\begin{array}{c}\text { Mean/ } \\
\text { year }\end{array}$ \\
\hline 2011 & $182 \mathrm{a}^{*}$ & $0.375 \mathrm{~cd}$ & $0.416 \mathrm{de}$ & $0.428 \mathrm{de}$ & $0.339 \mathrm{bc}$ & $0.461 \mathrm{ef}$ & $0.350 \mathrm{bc}$ & $0.491 \mathrm{f}$ & $0.359 \mathrm{bc}$ & $0.378 \mathrm{a}$ \\
\hline 2012 & & $0.694 \mathrm{~g}$ & $0.840 \mathrm{i}$ & $0.849 \mathrm{i}$ & $0.849 \mathrm{i}$ & $0.844 \mathrm{i}$ & & $0.754 \mathrm{~h}$ & $0.723 \mathrm{gh}$ & $0.698 \mathrm{~b}$ \\
\hline Mean for treatment & $0.244 \mathrm{a}$ & $0.534 \mathrm{c}$ & $0.628 \mathrm{~cd}$ & $0.638 \mathrm{~d}$ & $0.594 \mathrm{~cd}$ & $0.653 \mathrm{~d}$ & $0.386 \mathrm{~b}$ & $0.622 \mathrm{~cd}$ & $0.541 \mathrm{c}$ & \\
\hline
\end{tabular}

* - as in Table 4

Table 10. The effect of biostimulators on the percentage of rooted cuttings in Cornus alba 'Elegantissima' (2011 and 2012 .

The last column contains general means for all the treatments, separately for both years

\begin{tabular}{crrrrrrrrrr}
\hline Treatment/year & C & Rh AA & IBA & Alga 1x & Alga 2x & Alga 3x & Route 1x & Route 2x & Route 3x & $\begin{array}{c}\text { Mean/ } \\
\text { year }\end{array}$ \\
\hline 2011 & $55.7 \mathrm{abc}^{*}$ & $53.1 \mathrm{a}$ & $54.5 \mathrm{abc}$ & $83.4 \mathrm{fg}$ & $70.1 \mathrm{ef}$ & $68.9 \mathrm{ef}$ & $96.0 \mathrm{~g}$ & $93.2 \mathrm{~g}$ & $54.6 \mathrm{bc}$ & $69.7 \mathrm{a}$ \\
2012 & $62.9 \mathrm{bcd}$ & $66.6 \mathrm{cde}$ & $61.2 \mathrm{bcd}$ & $55.6 \mathrm{abc}$ & $73.3 \mathrm{ef}$ & $52.1 \mathrm{ab}$ & $66.7 \mathrm{cde}$ & $70 \mathrm{de}$ & $69.8 \mathrm{ef}$ & $64.4 \mathrm{a}$ \\
Mean for treatment & $59.4 \mathrm{ab}$ & $59.8 \mathrm{ab}$ & $57.8 \mathrm{a}$ & $\mathbf{6 9 . 5 \mathrm { c }}$ & $\mathbf{7 1 . 7 \mathrm { c }}$ & $\mathbf{6 0 . 6 \mathrm { ab }}$ & $\mathbf{8 1 . 7 \mathrm { d }}$ & $\mathbf{8 1 . 7 \mathrm { d }}$ & $\mathbf{6 2 . 2 \mathrm { b }}$ & \\
\hline
\end{tabular}

* - as in Table 4

Table 11. The effect of biostimulators on the degree of rooting in cuttings of Cornus alba 'Elegantissima' (2011 and 2012 ). The last column contains general means for all the treatments, separately for both years

\begin{tabular}{ccccccccccc}
\hline Treatment/year & C & Rh AA & IBA & Alga 1x & Alga 2x & Alga 3x & Route 1x & Route 2x & Route 3x & $\begin{array}{c}\text { Mean/ } \\
\text { year }\end{array}$ \\
\hline 2011 & $2.2 \mathrm{ab} *$ & $2.5 \mathrm{bcd}$ & $2.7 \mathrm{cde}$ & $2.8 \mathrm{def}$ & $2.5 \mathrm{bcd}$ & $3.5 \mathrm{~h}$ & $3.1 \mathrm{fgh}$ & $3.1 \mathrm{fgh}$ & $2.1 \mathrm{abc}$ & $2.7 \mathrm{a}$ \\
2012 & $2.6 \mathrm{bcd}$ & $3.0 \mathrm{fgh}$ & $3.2 \mathrm{gh}$ & $2.1 \mathrm{ab}$ & $2.9 \mathrm{def}$ & $2.0 \mathrm{a}$ & $2.4 \mathrm{bcd}$ & $2.4 \mathrm{bcd}$ & $2.4 \mathrm{bcd}$ & $2.6 \mathrm{a}$ \\
Mean for treatment & $2.4 \mathrm{a}$ & $2.7 \mathrm{ab}$ & $3.0 \mathrm{~b}$ & $2.5 \mathrm{ab}$ & $2.7 \mathrm{ab}$ & $2.7 \mathrm{ab}$ & $2.7 \mathrm{ab}$ & $2.8 \mathrm{ab}$ & $2.3 \mathrm{a}$ & \\
\hline
\end{tabular}

\footnotetext{
* - as in Table 4
} 
the second year was lower in cuttings treated with biostimulators, while in the Rhizopone - treated cuttings a reverse situation occurred.

The average photosynthetic rate $\left(\mathrm{P}_{\mathrm{n}}\right)$ of leaves ranged from 2.70 to $5.95 \mu \mathrm{mol} \mathrm{CO}_{2} \mathrm{~m}^{-2} \mathrm{~s}^{-1}$. The lowest average $\mathrm{P}_{\mathrm{n}}$ was in control cuttings, those treated with the auxin and sprayed once with AlgaminoPlant. All other treatments increased the intensity of photosynthesis. Generally, in 2011 the $\mathrm{P}_{\mathrm{n}}$ values were higher, especially in plants treated 2-3 times with AlgaminoPlant and three times with Route (Table 13).

The average transpiration rate of leaves $(\mathrm{E})$ ranged between 3.50 and $5.95 \mathrm{mmol} \mathrm{H}_{2} \mathrm{O} \mathrm{m}^{-2} \mathrm{~s}^{-1}$. All treatments significantly increased the transpiration efficiency relative to control. The highest, a nearly twofold increase, was observed after one or two applications of Route or three applications of AlgaminoPlant. In 2012, the average transpiration rate was $30-40 \%$ higher than in 2011 (Table 14).

The average value of stomatal conductance $\left(g_{s}\right)$ in untreated cuttings was $0.352 \mathrm{mmol} \mathrm{H}_{2} \mathrm{O} \mathrm{m}^{-2} \mathrm{~s}^{-1}$ and it was lower than in all the treatments (Table 15). The largest increase was in cuttings treated with the rooting powder where $g_{\mathrm{s}}$ was doubled relative to control. Generally, the stomatal conductance in 2012 was four times higher than in 2011. The largest difference between years were in cuttings sprayed once with AlgaminoPlant (8-fold).

\section{Discussion}

For this study, two popular cultivars of dogwood were chosen. They are known for their different responses in rooting. Also, differences in average rooting percentages were observed between the two cultivars in two years of experiments, being ca $67 \%$ and $79 \%$ for 'Aurea' and 'Elegantissima', respectively. However, in 2012, cuttings of 'Elegantissima' had a substantially lower rooting percentage than 'Aurea' (64\% versus $88 \%$ ). Year 2012 had much less rainfall

Table 12. The effect of biostimulators on respiration rates $\left(\mu \mathrm{mol} \mathrm{CO} \mathrm{m}^{-2} \mathrm{~s}^{-1}\right)$ in leaves of cuttings from Cornus alba 'Elegantissima' (2011 and 2012). The last column contains general means for all the treatments, separately for both years

\begin{tabular}{ccccrrrrrrr}
\hline Treatment/year & C & Rh AA & IBA & Alga 1x & Alga 2x & Alga 3x & Route 1x & Route 2x & Route 3x & $\begin{array}{c}\text { Mean/ } \\
\text { year }\end{array}$ \\
\hline 2011 & $0.8 \mathrm{bc}^{*}$ & $0.6 \mathrm{ab}$ & $0.9 \mathrm{~cd}$ & $2.0 \mathrm{i}$ & $2.0 \mathrm{i}$ & $1.6 \mathrm{~g}$ & $1.9 \mathrm{i}$ & $1.8 \mathrm{hi}$ & $1.6 \mathrm{~g}$ & $\mathbf{1 . 4 5} \mathrm{b}$ \\
2012 & $0.9 \mathrm{cde}$ & $0.8 \mathrm{~cd}$ & $1.1 \mathrm{de}$ & $0.6 \mathrm{a}$ & $1.3 \mathrm{f}$ & $1.2 \mathrm{ef}$ & $0.9 \mathrm{~cd}$ & $0.9 \mathrm{cde}$ & $1.4 \mathrm{~h}$ & $\mathbf{1 . 0 2 \mathrm { a }}$ \\
Mean for treatment & $\mathbf{0 . 8 5 \mathrm { a }}$ & $\mathbf{0 . 7 \mathrm { a }}$ & $\mathbf{1 . 0 \mathrm { ab }}$ & $\mathbf{1 . 3 \mathrm { bc }}$ & $\mathbf{1 . 6 5 \mathrm { c }}$ & $\mathbf{1 . 4 \mathrm { c }}$ & $\mathbf{1 . 4 \mathrm { c }}$ & $\mathbf{1 . 3 5 \mathrm { c }}$ & $\mathbf{1 . 5 \mathrm { c }}$ & \\
\hline
\end{tabular}

* - as in Table 4

Table 13. The effect of biostimulators on photosynthetic rates $\left(\mu \mathrm{mol} \mathrm{CO} \mathrm{Cm}^{-2} \mathrm{~s}^{-1}\right)$ in leaves of cuttings from Cornus alba 'Elegantissima' (2011 and 2012). The last column contains general means for all the treatments, separately for both years

\begin{tabular}{crrrrrrrrrr}
\hline Treatment/year & C & Rh AA & IBA & Alga 1x & Alga 2x & Alga 3x & Route 1x & Route 2x & Route 3x & $\begin{array}{c}\text { Mean/ } \\
\text { year }\end{array}$ \\
\hline 2011 & $4.6 \mathrm{bc}$ & $2.7 \mathrm{a}$ & $4.6 \mathrm{bc}$ & $4.0 \mathrm{ab}$ & $6.9 \mathrm{de}$ & $8.7 \mathrm{f}$ & $5.8 \mathrm{~cd}$ & $5.8 \mathrm{~cd}$ & $7.8 \mathrm{ef}$ & $5.65 \mathrm{~b}$ \\
2012 & $2.7 \mathrm{a}$ & $2.7 \mathrm{a}$ & $2.8 \mathrm{a}$ & $3.4 \mathrm{ab}$ & $3.5 \mathrm{ab}$ & $3.2 \mathrm{ab}$ & $4.1 \mathrm{~b}$ & $3.2 \mathrm{ab}$ & $3.6 \mathrm{ab}$ & $3.22 \mathrm{a}$ \\
Mean for treatment & $3.65 \mathrm{ab}$ & $2.7 \mathrm{a}$ & $3.7 \mathrm{ab}$ & $3.7 \mathrm{ab}$ & $\mathbf{5 . 2 \mathrm { cd }}$ & $5.95 \mathrm{~d}$ & $4.9 \mathrm{bcd}$ & $4.5 \mathrm{bc}$ & $5.7 \mathrm{~d}$ & \\
\hline
\end{tabular}

* - as in Table 4

Table 14. The effect of biostimulators on transpiration rate $\left(\mathrm{mmol} \mathrm{H}_{2} \mathrm{O} \mathrm{m}^{-2} \mathrm{~s}^{-1}\right)$ in leaves of cuttings from Cornus alba 'Elegantissima' (2011 and 2012). The last column contains general means for all the treatments, separately for both years

\begin{tabular}{|c|c|c|c|c|c|c|c|c|c|c|}
\hline Treatment/year & $\mathrm{C}$ & Rh AA & IBA & Alga $1 x$ & Alga $2 x$ & Alga $3 x$ & Route $1 \mathrm{x}$ & Route $2 \mathrm{x}$ & Route $3 x$ & $\begin{array}{c}\text { Mean/ } \\
\text { year }\end{array}$ \\
\hline 2011 & $1.8 \mathrm{a}^{*}$ & $5.0 \mathrm{~d}$ & $3.3 \mathrm{c}$ & $3.3 \mathrm{c}$ & $3.9 c$ & $5.2 \mathrm{de}$ & $6.2 \mathrm{gh}$ & $5.4 \mathrm{de}$ & $3.8 \mathrm{c}$ & $4.2 \mathrm{a}$ \\
\hline 2012 & $5.2 \mathrm{~d}$ & 6.4ghi & $5.5 \mathrm{de}$ & $7.0 \mathrm{j}$ & $6.2 \mathrm{fg}$ & 6.7 hij & 6.6 ghij & $6.8 \mathrm{ij}$ & $5.6 \mathrm{ef}$ & $6.2 \mathrm{~b}$ \\
\hline Mean for treatment & $3.5 \mathrm{a}$ & $5.7 \mathrm{de}$ & $4.4 \mathrm{~b}$ & $5.15 \mathrm{~cd}$ & $5.05 \mathrm{bcd}$ & $5.95 \mathrm{e}$ & $6.4 \mathrm{e}$ & $6.1 \mathrm{e}$ & $4.7 \mathrm{bc}$ & \\
\hline
\end{tabular}

* - as in Table 4

Table 15. The effect of biostimulators on stomatal conductance $\left(\mathrm{g}_{\mathrm{s}}\right)\left(\mathrm{mmol} \mathrm{H}_{2} \mathrm{O} \mathrm{m}^{-2} \mathrm{~s}^{-1}\right)$ in leaves of cuttings from Cornus alba 'Elegantissima' (2011 and 2012). The last column contains general means for all the treatments, separately for both years

\begin{tabular}{ccrrrrrrrrr}
\hline Treatment/year & C & Rh AA & IBA & Alga 1x & Alga 2x & Alga 3x & Route 1x & Route 2x & Route 3x & $\begin{array}{c}\text { Mean/ } \\
\text { year }\end{array}$ \\
\hline 2011 & $0.106 \mathrm{a}$ & $0.336 \mathrm{~d}$ & $0.160 \mathrm{ab}$ & $0.113 \mathrm{a}$ & $0.165 \mathrm{ab}$ & $0.202 \mathrm{bc}$ & $0.220 \mathrm{bc}$ & $0.248 \mathrm{c}$ & $0.225 \mathrm{bc}$ & $\mathbf{0 . 1 9 7} \mathrm{a}$ \\
2012 & $0.598 \mathrm{e}$ & $1.079 \mathrm{j}$ & $0.733 \mathrm{f}$ & $0.905 \mathrm{i}$ & $0.722 \mathrm{f}$ & $0.747 \mathrm{fg}$ & $0.814 \mathrm{~h}$ & $0.800 \mathrm{gh}$ & $0.765 \mathrm{fgh}$ & $\mathbf{0 . 7 9 6} \mathrm{b}$ \\
Mean for treatment & $\mathbf{0 . 3 5 2 \mathrm { a }}$ & $\mathbf{0 . 7 0 7 \mathrm { d }}$ & $\mathbf{0 . 4 4 6 \mathrm { b }}$ & $\mathbf{0 . 5 0 9} \mathrm{bc}$ & $\mathbf{0 . 4 4 3} \mathrm{b}$ & $\mathbf{0 . 4 7 5} \mathrm{bc}$ & $\mathbf{0 . 5 1 7} \mathrm{bc}$ & $\mathbf{0 . 5 2 4} \mathrm{c}$ & $\mathbf{0 . 4 9 5} \mathrm{bc}$ & \\
\hline
\end{tabular}

\footnotetext{
* - as in Table 4
} 
than 2011 and this might have affected the condition of stock plants.

In the yellow-leaved 'Aurea', all treatments improved rooting relative to control. In 'Elegantissima' an improvement was observed only after applications of AlgaminoPlant, a seaweed-based preparation, and one or two applications of Route. Whapham et al. (2006) showed a positive effect of a seaweed extract on root length and root mass in Vigna sinensis. In Arabidopsis thaliana, Rayorath et al. (2008) observed an enhancement of the root system development following applications of an extract from seaweed Ascophyllum nodosum. Also, Thorsen et al. (2010) showed a positive effect of the extract from seaweed Laminaria digitata on the germination, root growth and plant development in several herbaceous plants.

Route contains zinc. Due to a deficit of this element tryptophan synthesis is impaired what directly affects auxin biosynthesis and limits plant growth (Broadley et al. 2007). Yamashita et al. (2006) proved that zinc combined with IAA increased rooting of cuttings in Mangifera indica. Similar observations were reported by Szydło et al. (2007) who tested effects of the IBA co-factors on rhizogenesis in cuttings of Hedera helix and Ilex $\times$ meserveae. In their tests with ninebark (Physocarpus opulifolius) the same authors observed the best root ball development following three applications of Route (Pacholczak and Szydło 2008). The enhancement of the root system development after applications of $0.1 \%$ Route was also observed in several container-grown ornamental shrubs (Pacholczak et al. 2009). All these observations, including the results of this study on dogwood, indicate that biostimulators enhance rhizogenesis but their efficiency may vary depending on the species, cultivar, the biostimulator applied, and the number of treatments. This means that at least some biopreparations do have serious potential in commercial production but the protocols and application regimes may have to be custom fitted to each specific target.

Until the first roots develope during rooting of cuttings, the efficiency of the photosynthetic apparatus is limited and less energy substrates are available. Such substrates are indispensable for respiration which in turn provides energy for rhizogenesis. This phenomenon is especially important in plants with long rooting periods, such as most woody plants (Couvillon 1988). A relationship between the photosynthetic rate and respiration may well be reflected by the so-called carbon balance $\mathrm{P}_{\mathrm{n}} / \mathrm{R}_{\mathrm{d}}$. In autotrophic organisms, growth is possible only when this ratio is above 1 (Chu et al. 2010). For dogwood cuttings of 'Aurea', the ratio in both years was 3.4 to 7.5 , while in 'Elegantissima' it was 3.1 to 4.3 . Both ranges fit well with the literature data where the range of 1-20 for the carbon balance is reported (Kocurek et al. 2009; Chołuj et al. 2010; Kalaji and Łoboda 2010).
Here, the highest values were in dogwood cuttings treated twice or three times with AlgaminoPlant or twice in Route. Changes in the carbon balance were mainly due to increases in the respiration rate and not to changes in photosynthesis.

Generally, in both cultivars the respiration rates were higher after applications of biostimulators relative to controls. It was somewhat higher in 'Elegantissima' than in 'Aurea'. In the former, AlgaminoPlant caused a more pronounced increase in respiration than in 'Aurea', where the lowest rate was observed after two applications. The effects of Route on respiration also varied in both cultivars. In 'Elegantissima' each treatment with Route resulted in a considerable increase in the respiration rate while in 'Aurea' a similar increase was in cuttings sprayed twice or three times with the preparation and it still reached a lower value than in 'Elegantissima'. It should be noted that the $R_{d}$ values for dogwood cuttings are much lower than those reported for woody plants grown for biofuels such as rose and willow (Chołuj et al. 2010).

An increased photosynthetic rate was observed in both cultivars after applications of biostimulants, while for auxin only in 'Aurea'. This is similar to the results of Gawrońska et al. (2008) and Przybysz et al. (2008) after application of Asahi SL on rape. Also Costa et al. (2001) reported similar phenomenon on rooted roses.

A comparison of the general means of the parameters for both cultivars in both years of experiments does not show any clear relationship between the physiological parameters measured and rhizogenesis even though the effects of treatments varied from year to year and between two cultivars. In 2011, the percentages and degrees of rooting were similar in both cultivars, but the respiration rate in 'Elegantissima' was twice as high as in 'Aurea' and the photosynthetic rate by $29 \%$ higher. On the other hand, 'Aurea' had transpiration 29\% higher than 'Elegantissima', and the stomatal conductance was almost twice as high. In 2012, the year when stock plants grew under less rainfall, the percentages and degrees of rooting were generally much better in 'Aurea' with higher respiration and transpiration rates than in 'Elegantissima' where the photosynthetic rate and stomatal conductance showed lower values.

In 'Aurea', the percentage of rooting was significantly higher in 2012 than 2011, and this was accompanied by a higher mean respiration, transpiration and stomatal conductance rates. The treatments which improved rooting (AlgaminoPlant 1-3x, Route $1 \mathrm{x}$ and $2 \mathrm{x}$ ) increased all parameters tested while the inefficient triple application of Route increased only four of them (Table 16). In 'Elegantissima' the transpiration rates and stomatal conductance were also higher in 2012 but there were no significant differ- 
Table 16. Comparison of the effects of treatments on parameters from 2 years measured in cuttings of Cornus alba 'Aurea': 0 - equal to control (no effect), $0+$ slight (significant) increase relative to control, + a significant increase relative to control, - a significant decrease relative to control.

\begin{tabular}{lcccccc}
\hline $\begin{array}{c}\text { Treat- } \\
\text { ments }\end{array}$ & $\begin{array}{c}\text { Rooting } \\
\%\end{array}$ & $\begin{array}{c}\text { Respi- } \\
\text { ra- } \\
\text { tion }\end{array}$ & $\begin{array}{c}\text { Photo- } \\
\text { synthe- } \\
\text { sis }\end{array}$ & $\begin{array}{c}\text { Carbon } \\
\text { balance }\end{array}$ & $\begin{array}{c}\text { Tran- } \\
\text { spira- } \\
\text { tion }\end{array}$ & $\begin{array}{c}\text { Stoma- } \\
\text { tal } \\
\text { con- } \\
\text { duct. }\end{array}$ \\
\hline Rh & $0+$ & $0+$ & + & 0 & + & + \\
IBA & + & $0+$ & + & 0 & + & + \\
A 1x & + & $0+$ & 0 & $0-$ & + & + \\
A 2x & + & 0 & + & $0+$ & + & + \\
A 3x & + & + & + & + & + & + \\
R 1x & + & $0+$ & 0 & 0 & $0+$ & + \\
R 2x & + & + & + & $0+$ & + & + \\
R 3x & 0 & + & $0+$ & $0-$ & + & + \\
2011 & & & $\uparrow$ & $\uparrow *$ & & \\
2012 & $\uparrow *$ & $\uparrow$ & & & $\uparrow$ & $\uparrow$ \\
\hline
\end{tabular}

* - values higher as compared to 2012/2011

ences in rooting percentage (Table 17). Average values of all other physiological parameters were higher in 2011 for this cultivar. Treatments which positively affected rhizogenesis also increased the values of more parameters than did treatment with Rhizopon which proved ineffective relative to control cuttings.

The data from literature as well as the results of the present work indicate that plants treated with biostimulators have an elevated photosynthetics rate (Gawrońska et al. 2008; Przybysz et al. 2008; Przybysz et al. 2010). The elevated photosynthesis $\left(P_{n}\right)$ is accompanied by an increased stomatal conductance what may lead to an increase in transpiration rate. Data on photosynthetic indexes of water use (WUE and $\mathrm{WUE}_{\mathrm{i}}$ ) is lacking. Their comparison might allow

Table 17. Comaparison of the effects of treatments on parameters from 2 years measured in cuttings of Cornus alba 'Elegantissima': 0 - equal to control (no effect), $0+$ slight increase relative to control, + a significant increase relative to control, - a significant decrease relative to control.

\begin{tabular}{lcccccc}
\hline $\begin{array}{l}\text { Treat- } \\
\text { ments }\end{array}$ & $\begin{array}{c}\text { Rooting } \\
\%\end{array}$ & $\begin{array}{c}\text { Respi- } \\
\text { ration }\end{array}$ & $\begin{array}{c}\text { Photo- } \\
\text { synthe- } \\
\text { sis }\end{array}$ & $\begin{array}{c}\text { Carbon } \\
\text { balance }\end{array}$ & $\begin{array}{c}\text { Tran- } \\
\text { spira- } \\
\text { tion }\end{array}$ & $\begin{array}{c}\text { Stoma- } \\
\text { tal } \\
\text { con- } \\
\text { duct. }\end{array}$ \\
\hline Rh & 0 & 0 & + & 0 & + & + \\
IBA & 0 & + & $0+$ & 0 & + & + \\
A 1x & + & + & $0+$ & 0 & + & + \\
A 2x & + & + & + & 0 & + & + \\
A 3x & 0 & + & + & 0 & + & + \\
R 1x & + & + & + & 0 & + & + \\
R 2x & + & + & + & 0 & + & + \\
R 3x & 0 & + & + & 0 & + & + \\
2011 & 0 & $\uparrow *$ & $\uparrow$ & $\uparrow$ & & + \\
2012 & 0 & & & & $\uparrow$ & $\uparrow$ \\
\hline
\end{tabular}

* - values higher as compared to 2012/2011 to evaluate the effects of environmental factors on an innate relationship between stomatal conductance and rate of photosynthesis through transpiration (Borowski et al. 2010).

The results presented here demonstrate that the two biopreparations (AlgaminoPlant and Route) tested do have potential in commercial horticultural production but their effectiveness may be different in different species, different cultivars and under different climatic conditions. However, although their applications produce changes in the parameters of gas exchange during rooting, no direct relationship could be established between such changes and rhizogenesis. Perhaps, the crucial element is how the cuttings distribute the positive carbon balance to their principal organs: leaves, stems and roots. Thus, a detailed study of photoassimilate distribution pattern should be performed with both cultivars studied. An analysis of dry mass accumulation by individual plants might be useful to recognize this pattern (Evans 1972, Hunt 1978, Pietkiewicz 1985a,b).

\section{Acknowledgments}

This research was supported by the State Comitee for Scientific Research as a part of the Project: 'The intensification of propagation ornamental shrubs with biostimulants using' (NN 310725140).

\section{References}

Anyszka Z., Pałczyński J., 2006. Badania skuteczności biologicznej niektórych środków firmy Varichem T. Ostrowski. Instytut Warzywnictwa im. Emila Chroboczka - Pracownia Herbologii, Skierniewice.

Bai N.R., Banu N.R.L., Prakash J.W., Goldi S.J., 2007. Effects of Asparagopsis taxiformis extract on the growth and yield of Phaseolus aureus. Journal of Basic and Applied Biology 1: 6-11.

Basak A., 2008. Klasyfikacja biostymulatorów na podstawie opinii badaczy oraz firm chemicznych krajowych i zagranicznych. Wieś Jutra 5: 31-34.

Broadley M., White P., Hammond J., Zelko I., Lux A. 2007. Zinc in plants. New Phytologist 173: 677-702. http://dx.doi.org/10.1111/j.14698137.2007.01996.x

Borowski J., Łoboda T., Pietkiewicz S. 2009. Photosynthetic rates and water use efficiencies in three climber species grown in different exposures at urban and suburban sites. Dendrobiology 62: 55-61.

Chołuj D., Podlaski S., Pietkiewicz S., Wiśniewski G. 2010. Parametry fizjologiczne determinujące plon biomasy roślin energetycznych. In: Nowoczesne technologie pozyskiwania i energetycznego wy- 
korzystywania biomasy (red. Bocian P., Golec T., Rakowski J.). Instytut Energetyki, Warszawa, pp. 69-88.

Chu Z., Lu Y., Chang J., Wang M., Jiang H., He J., Peng Ch., Ge Y. 2010. Leaf respiration/photosynthesis relationship and variation: an investigation of 39 woody and herbaceous species in east subtropical China. Trees DOI 10.1007/s00468-0100506-x Published online.

Costa J.M., Challa H., Meeteren U., van de Pol P.A. 2001. Photosynthates: mainly stored and yet limiting in propagation of rose cuttings. Acta Horticulturae 547: 167-174.

Couvillon G.A., 1988. Rooting responses to different treatments. Acta Horticulturae 227: 187-196.

Dobrzański A., Anyszka Z., Elkner K. 2008. Reakcja marchwi na ekstrakty pochodzenia naturalnego z alg z rodzaju Sargassum - AlgaminoPlant i z leonardytu - HumiPlant. Journal of Research and Applications in Agricultural Engineering 53: 53-58.

Evans G.C. 1972. The quantitative analysis of plant growth. Blackwell scientific publication. Oxford-London-Edinburgh-Melbourne.

Fraser G.A., Percival G.C. 2003. The influence of biostimulants on growth and vitality of three urban tree species following transplanting. Arboricultural Journal 27: 43-57. http://dx.doi.org/10.10 80/03071375.2003.9747361

Gawrońska H., Przybysz A., Szalacha E., Słowiński A. 2008. Physiological and molecular mode of action of Asahi SL biostimulator under optimal and stress conditions. In: Biostimulators in modern agriculture, Wieś Jutra, Warszawa, pp. 54-76.

Hartmann H.T., Kester D.E., Davies F.T., Geneve R.L. 2002. Plant propagation. Principles and practices. Seventh edition. Prentice Hall. Upper Saddle River, New Jersey.

Horne M.R.L., Leitch M.H. 2006. A pot evaluation of the effects of zinc ammonium acetate on grain yield in spring barley. Tests of Agrochemicals and Cultivars, 27.

Hunt R., 1978. Plant growth analysis. Studies in Biology no 96. London.

Jankiewicz L.S. 1997. Regulatory wzrostu i rozwoju roślin. Zastosowanie $\mathrm{w}$ rolnictwie, leśnictwie i w kulturach tkanek - tom 2. PWN, Warszawa, pp. 11-16.

Kalaji M.H., Łoboda T. 2010. Fluorescencja chlorofilu w badaniach stanu fizjologicznego roślin. Wydawnictwo SGGW, Warszawa.

Khan W., Rayirath U.P., Subramanian S., Jitesh M.N., Rayorath P., Hodges D.M., Critchley A.T., Craigie J.S., Norrie J., Prithiviraj B. 2009. Seaweed extracts as biostimulants of plant growth and development. Journal of Plant Growth Regulation
28: 386-399. http://dx.doi.org/10.1007/s00344009-9103-X

Kryt M. 2010. Rooting ability of dogwood cultivars. (Personal communication).

Kocurek M., Tokarz K., Pilarski J. 2009. Stem photosynthesis and its importance to the carbon budgets of plants. Wiadomości Botaniczne 53: 7-20.

Matysiak K., Kaczmarek S., Kierzek R., Kardasz P. 2010. Effect of seaweeds extracts and humic and fulvic acids on the germination and early growth of winter oilseed rape (Brassica napus L.). Journal of Research and Applications in Agricultural Engineering 55: 28-32.

Pacholczak A., Szydło W. 2008. Effect of ammonium zinc acetate on rooting of stem cuttings in Physocarpus opulifolius. Annals of Warsaw Agricultural University, Horticulture Landscape Architecture 29: 59-64.

Pacholczak A., Szydło W., Łukaszewska A. 2005. Effectiveness of foliar auxin application to stock plants in rooting of stem cuttings of ornamental shrubs. Propagation of Ornamental Plants 5: 100-106.

Pacholczak A., Szydło W., Grzesiak A. 2009. Effect of naphtalene-1-acetic acid on growth of the container-produced ornamental shrubs and development of their root system. Annals of Warsaw Agricultural University, Horticulture Landscape Architecture 30: 109-113.

Pacholczak A., Szydło W., Jacygrad E. 2010. Wpływ preparatów Amino Total i Biochikol 020 PC na ukorzenianie sadzonek pędowych Berberis thunbergii i Cornus alba. Zeszyty Problemowe Postępów Nauk Rolniczych 551: 219-229.

Pacholczak A., Szydło W., Jacygrad E., Federowicz M. 2012. Effect of auxins and the biostimulator AlgaminoPlant on rhizogenesis in stem cuttings of two dogwood cultivars (Cornus alba 'Aurea' and 'Elegantissima'). Acta Scientiarum Polonorum Hortorum Culturs 11: 93-103.

Pietkiewicz S. 1985a. Wskaźnikowa analiza wzrostu roślin. Wiadomości Botaniczne 29: 29-42.

Pietkiewicz S. 1985b. Metodyka prac doświadczalnych i technika obliczeń we wskaźnikowej analizie wzrostu roślin. Wiadomości Botaniczne 29: 111-126.

Przybysz A., Małecka-Przybysz M., Słowiński A., Gawrońska H. 2008. The effect of Asahi SL on growth, efficiency of photosynthetic apparatus and yield of field grown oil seed rape. In: Biostymulators in modern agriculture, Field Crops, Wieś Jutra, Warszawa, pp. 7-17.

Przybysz A., Wrochna M., Słowiński A., Gawrońska H. 2010. Stimulatory effect of Asahi SL on selected plant species. Acta Scientiarum Polonorum Hortorum Culturs 9: 53-64. 
Rayorath P., Khan W., Palanisamy R., MacKinnon S.L., Stefanova R., Hankins S.D., Critchley A.T., Prithiviraj B. 2008. Extracts of the brown seaweed Ascophyllum nodosum induce gibberellic acid $\left(\mathrm{GA}_{3}\right)$ - independent amylase activity in barley. Journal of Plant Growth Regulation 27: 370-379. http:// dx.doi.org/10.1007/s00344-008-9063-6

Szydło W., Maksim P. 1997. Wpływ auksyn dostarczanych dolistnie na ukorzenianie sadzonek pędowych wybranych gatunków z rodzaju Juniperus. Mat. konf. „Rozmnażanie Roślin Ogrodniczych”. ISiK, Skierniewice, pp. 58-61.

Szydło W., Pacholczak A. 2001 Wpływ opryskiwania auksynami roślin matecznych Hedera helix na proces rizogenezy sadzonek pędowych. Mat. konf. „Szkółkarstwo ozdobne na progu nowego milenium". ISiK, Skierniewice, pp. 143-148.

Szydło W., Pacholczak A., Łukaszewska A. 2007. Rooting of stem cuttings of Hedera helix 'Arborescens' as affected by zinc treatment. Annals of Warsaw Agricultural University, Horticulture Landscape Architecture 28: 79-86.
Thorsen M.K., Woodward S., McKenzie B.M. 2010. Kelp (Laminaria digitata) increases germination and affects rooting and plant vigour in crops and native plants from an arable grassland in the outer Hebrides, Scotland. Journal of Costal Conservation 14: 239-247. http://dx.doi.org/10.1007/ s11852-010-0091-6

Whapham C.A., Blunden G., Jenkins T., Hankins S.D. 2006. Significance of betaines in the increased chlorophyll content of plants treated with seaweed extract. Journal of Applied Phycology 5: 231-234. http://dx.doi.org/10.1007/BF00004023

Wójcik A.R., Laudański Z. 1989. Planowanie i wnioskowanie statystyczne w doświadczalnictwie. PWN, Warszawa, p. 130.

Yamashita K., Okamura S., Honsho C., Tetsumura T. 2006. Zinc treatment in combination with auxin enhances rooting of cuttings in Taiwan Native Strain of mango (Mangifera indica L.). Nettai Nogyo 50: 76-81. 